\title{
ANALISA PENGARUH VARIASI KOMPOSISI BAHAN LIMBAH DARI SERAT KELAPA MUDA, BATANG PISANG DAN KERTAS BEKAS TERHADAP KEKUATAN BENDING SEBAGAI PAPAN KOMPOSIT
}

\author{
Enda Apriani \\ Prodi Teknik Mesin Universitas Proklamasi 45 \\ Email: endaapriani81@gmail.com \\ Jl. Proklamasi No. 1 Babarsari Sleman Yogyakarta
}

\begin{abstract}
The composite is a combination of two or more materials to produce a new material with unique properties compared to the nature of the base material prior to mixing and surface bonding occurs between each constituent material. The purpose of this research is to know the influence of waste material composition from plant fiber,that is young coconut fiber, banana stem, and calendarwaste paper to bending strength on composite board by using Epoxy resin wood type.

The process of printing the composite board is done in the Laboratory of Integrated Mechanical Engineering University Proklamasi 45 Yogyakarta. The three raw materials that have been crushed and dried, mixed with the breaking time of each 5"and 10" with their respective ingredients composition, namely Young Coconut Fiber: Banana Stem Fiber: Calendar Waste Paper = 25: 25:50; 25: 50:25; 50: 25: 25 (\%).Each treatment was repeated 3 times. Observation was done by calculating raw material composition and time of destruction process against bending strength of composite board which resulted very significant effect on water content, fracture, and flexibility of composite board. Bending strength testing is performed using a robust Universal TestingMachine (UTM).

The result of this research produced the most optimum material composition of bending strength into composite board, ie composition III with the duration of destruction for 5", that is the average MoE value of 17.069,76 kg / $\mathrm{cm}^{2}$ and the average value of MoR is $83,78 \mathrm{~kg} / \mathrm{cm}^{2}$. From this research is expected to get new engineering technique from agriculture waste become composite board with economic value.
\end{abstract}

Keywords: Young coconutiber, banana stem, waste paper, composite, bending

\section{PENDAHULUAN}

Komposit merupakan salah satu jenismaterial di dalam dunia teknik yang dibuat dengan penggabungan dua macam bahan yang mempunyai sifat berbeda menjadisatu material baru dengan sifat yang berbeda pula.

Dalam bidang teknologi material, bahan-bahan serat alam merupakan kandidat sebagai bahan penguat untuk dapat menghasilkan bahan komposit yang ringan, kuat, ramah lingkungan serta ekonomis. Salah satunya adalah bahanbahanserat alam dari limbah pertanian. Sisa pengolahan hasil pertanian yang jumlahnya melimpah di sekitar lingkungan kita, seperti serat kelapa muda dan batang pisang dapat dijadikan sebagai penguat untuk komposit polimer.

Tanaman kelapa merupakan tanaman yang banyak dijumpai di seluruh pelosok Nusantara, sehingga hasil alam berupa kelapa di Indonesia sangat melimpah. Sampai saat ini pemanfaatan limbah berupa sabut kelapa masih terbatas pada industri-industri mebel dan kerajinan rumah tangga dan belum diolah menjadi produk teknologi. Limbah serat buah kelapa sangat potensial digunakan sebagai penguat bahan baru pada komposit. Beberapa keistimewaan pemanfaatan serat sabut kelapa sebagai bahan baru rekayasa antara lain menghasilkan bahan baru komposit alam yang ramah lingkungan dan 
mendukung gagasan pemanfaatan serat sabut kelapa menjadi produk yang memiliki nilai ekonomi dan teknologi tinggi (Amin\& Samsudi, 2010).

Permasalahan sampah kertas tidak terlepas dari permasalahan sampah secara keseluruhan. Salah satu upaya pemerintah dalam mengatasi permasalahan sampah kertas antara lain dengan mendorong usaha guna ulang dan daur ulang sampah kertas. Saat ini sekitar sampah kertas dapat dikumpulkan oleh pemulung untuk dijual ke lapak. Jumlah timbunan sampah kertas bisa mencapai sekitar $10 \%$ dari jumlah keseluruhan sampah. Masing-masing jenis kertas juga memiliki karakteristik tersendiri kemampuannya untuk didaur ulang dan prosesnya juga berbeda-beda (Sucipto, 2012).

Melimpahnya limbah padat dari pertanian dan limbah kertas, serta pemakaian kayu/papan yang meningkat, maka pembuatan papan komposit merupakan salah satu alternatif dalam pemanfaatan limbah-limbah tersebut untuk menghasilkan produk-produk inovatif dan kreatif sebagai bahan dasar pengganti kayu/papan dan juga untuk bahan baku di industri kreatif. Pemanfaatan limbah serattanaman dan kertas bekas dapat menaikkan nilai ekonomis masing-masing material.

Tujuan dari penelitian ini adalah untuk mengetahui pengaruh komposisi bahan serat tanaman dari serat kelapa muda dan batang pisang, serta kertas bekas jenis kalender terhadap kekuatan bending pada papan komposit. Melalui penelitian ini diharapkan bisa dihasilkan komposisi yang optimal dalam mengolah limbah pertanian dan sampah kertas yang tidak termanfaatkan secara maksimal menjadi papan komposit yang bernilai ekonomis.

\section{LANDASAN TEORI}

\section{A. Komposit}

Komposit merupakan kombinasi dari dua bahan atau lebih untuk menghasilkan material baru dengan sifat yang unik dibandingkan sifat material dasar sebelum dicampur dan terjadi ikatan permukaan antara masing-masing material penyusun.

Salah satu keuntungan material komposit adalah kemampuan material tersebut untuk dapat diarahkan, sehingga kekuatannya dapat diatur hanya pada arah tertentu yang kita kehendaki. Hal ini yang dinamakan "tailoring properties". Beberapa sifat istimewa dari komposit, yaitu ringan, kuat, tidak terpengaruh korosi, dan mampu bersaing dengan logam, dengan tidak kehilangan karakteristik dan kekuatan mekanisnya.

Secara umum bahan komposit terdiri dari dua macam, yaitu bahan komposit partikel (particulatecomposite) dan bahan komposit serat (fibercomposite). Papan partikel yang terbuat dari serat dan dicampur dengan perekat, sehingga kemudian dapat dikempa menjadi papan.

Beberapa penelitian terdahulu terkait dengan penelitian ini seperti yang dilakukan oleh Sudarsono, dkk (2010), bahwa beberapa alternatif telah dikembangkan dalam rangka untuk mengatasi makin langkanya bahan baku kayu dari alam. Dimana dengan memanfaatkan perkembangan teknologi telah diciptakan produk-produk turunan dari kayu seperti papan partikel, papan semen, papan serat, dan lain sebagainya. Melihat manfaat serat kelapa yang begitu berpotensi untuk dikembangkan ini, akan menarik sekali untuk diadakan suatu penelitian, bagaimana supaya serat kelapa dapat lebih bermanfaat. Salah satunya yaitu dimanfaatkan sebagai pembuatan papan partikel yang selanjutnya digunakan untuk kebutuhan rumah tangga atau pun dalam dunia industri. Penelitian ini menggunakan $\mathrm{NaOH}$ sebagai larutan pemasak yang umum digunakan pada industri pulp. Penggunaan larutan pemasak ini didasarkan karena alasan ekonomis (Saleh, dkk, 2009).

Menurut Sari, dkk (2011) tujuan dari penelitiannya adalah untuk mengetahui 
ketahanan bending komposit hybrid serat batang kelapa/serat gelas dengan matrik urea formal dehyde. Hasil pengujian bending tertinggi dalam penggunaan hybrid serat batang kelapa/fiber glass dengan fraksi volume serat batang kelapa/fiber glass, yaitu $10: 20$ (\%), sebesar 22,7 N/mm², 15 : 15 (\%) sebesar $19,6 \mathrm{~N} / \mathrm{mm}^{2}$ dan $20: 10(\%)$ sebesar 17,37 $\mathrm{N} / \mathrm{mm}^{2}$.

Penggunaan pengisi alamiah sebagai penguat pada material komposit memberikan beberapa keuntungan dibanding bahan pengisi mineral, diantaranya yaitu kuat dan pejal, ringan, ramah lingkungan, sangat ekonomis dan sumber dapat diperbaharui. Tetapi disisi lain, pengisi alamiah juga memiliki kelemahan dan kekurangan, diantaranya yaitu mudah terurai karena kelembaban, adhesi permukaan yang lemah pada polimer hidrofobik, ukuran pengisi yang tidak seragam, tidak cocok dipakai pada temperatur tinggi dan mudah terpengaruh pada serangan serangga dan jamur.

Bahan komposit partikel pada umumnya lebih lemah dibandingkan bahan komposit serat. Bahan komposit partikel mempunyai beberapa keunggulan, seperti ketahanan terhadap aus, tidak mudah retak dan mempunyai daya pengikat dengan matrik yang baik.

Unsur utama komposit adalah serat yang mempunyai banyak keunggulan.Oleh karena itu, bahan komposit serat yang paling banyak dipakai. Bahan komposit serat tediri dari serat-serat yang diikat oleh matrik yang saling berhubungan.Bahan komposit serat ini terdiri dari dua macam, yaitu serat panjang (continuos fiber) dan serat pendek (short fiber atau whisker). Dalam dunia industri mulai dikembangkan penggunaan komposit serat daripada mengunakan bahan partikel. Bahan komposit serat mempunyai beberapa keunggulan yang utama, yaitu strong (kuat), stiff (tangguh), dan lebih tahan terhadap panas pada saat didalam matrik.
Dalam perkembangan teknologi pengolahan serat, membuat bahan komposit serat sekarang makin diunggulkan dibandingkan material matrik yang digunakan. Guna memperoleh hasil yang maksimal, cara yang digunakan untuk mengkombinasi serat berkekuatan tarik tinggi dan bermodulus elastisitas tinggi dengan matrik yang bermassa ringan, berkekuatan tarik rendah, serta bermodulus elastisitas rendah, semakin banyak dikembangkan.

Secara umum, dikenal tiga kelompok kompositberdasarkan penguat yang digunakannya, yaitu :

1) Komposit berserat, yaitu komposit berpenguat serat, antara lain seperti serat gelas (fiberglass), serat karbon, serat grafit sampai serat baja.

2) Komposit laminer atau laminat, yaitu komposit berpenguat dalam bentuk lembaran, seperti kertas dan kain.

3. Komposit partikel atau partikulat, yaitukomposit berpenguat dalam bentuk butiran, sepertikerikil, pasir, filler lain dalam matrik kontinyu.

Pada saat membuat hamparan, penaburan partikel (yang sudah dicampur sama perekat) dapat dilakukan secara acak (arah serat partikel tidak diatur) atau arah serat diatur, misalnya sejajar atau bersilangan tegak lurus. Untuk yang disebutkan terakhir dipakai partikel yang relatif panjang, biasanya berbentuk untai sehingga disebut papan untuk terarah.

\section{B. Perekat (Adhesive)}

Papan turunan ini dibuat dengan menggunakan bahan penolong seperti perekat, akan membantu terbentuknya ikatan antar serat yang lebih kuat sehingga dihasilkan sifat papan yang baik. Dalam penelitian ini dipilih resin Epoxy sebagai bahan pengikat dan material lainnya disusun secara acak sehingga terbentuk material komposit. Perekat kayu ini adalah yang paling banyak digunakan dalam dunia industri mebel Jepara. Jenis perekat kayu yang satu ini terdiri dari 2 komponen 
utama, yaitu resin dan hardener. Sifatnya mengisi permukaan/komponen yang disambung, memiliki tekstur yang keras dan sangat kuat tahan air dan bahan kimia, serta tahan temperatur yang relatif tinggi.

Dengan sifat-sifatnya tersebut, pada dasarnya perekat ini sangat bagus untuk aplikasi mebel furniture. Proses pencampurandua komponen tersebut harus dilakukan dengan tepat, karena setelah dua komponen tercampur sempurna maka reaksi pengeringan pun dimulai. Pengeringan campuran perekat ini bisa mencapai 100 menit sebelum kemudian mengeras sempurna dan tidak dapat digunakan lagi, Jika terlalu banyak membuat campuran maka akan sangat tidak ekonomis. Kekurangan dari bahan lem perekat kayu epoxy adalah memiliki "glue line" / bekas lem yang cukup terlihatdan juga sifat kerasnya yang justru menjadi bumerang karena jika permukaan komponen yang disambung bergerak / menyusut sedikit saja maka perekat akan pecah/retak. Untuk aplikasi mebel taman / luar ruangan (outdoor furniture) mungkin kurang cocok jika menggunakan bahan perekat ini. Resin jenis ini memiliki sifat lebih lama mengering dibanding resin poliester.

Ada keuntungan dan kerugian di dalam penggunaan perekat pada papan komposit.

Keuntungannya :

1. Perekat mampu menghubung berbagai jenisbahan berbeda yang modulus dan ketebalannya berbeda.

2. Memudahkan penyambungan dan pabrikasi bentuk-bentuk rumit.

3. Perekat memungkinkan terjadinya produk akhir dengan penampilan memuaskan, permukaan dankantun bagus, tidak ada rongga dan tidak ada bagianyang menonjol seperti sekrap.

4. Perekat mudah dan cepat pakai.

5. Kekuatan perekat amat tinggi dan biayanyaekonomis.

Kerugiannya :
1. Dalam hal tertentu proses perekatannya terkadangrumit.

2. Kuat ikatannya optimalnya tidak seketika tercapai.

3. Perekat kebanyakan memiliki daya hantar listrikdan termal kurang baik, kecuali bila diisi dengan filler tertentu.

4. Perekat tidak seratus persen tahan terhadap panas,diuji, kerusakan oleh organisme, bahan kimia,radiasi, dan kondisi pemakaian ekstrim.

Perkembangan teknologi dewasa ini menuntut setiap industri menghasilkan produk yang ramah lingkungan dan lebih ekonomis, dengan memanfaatkan sumber daya alam yang dapat diperbaharui. Didalam pembuatan suatu komposit, bahan pengisi yang mengandung selulosa menjadi perhatian yang besar karena kemampuannya sebagai penguat pada polimer - polimer termoplastik dengan titik peleburan yang rendah. Salah satu alternatif yang dapat digunakan sebagai bahan pengisi adalah selulosa yang diperoleh dari serat kelapa muda dan batang pisang.

\section{Pohon Kelapa (Cocos nucifera L)}

Pohon kelapa merupakan tanaman tropis yang penting bagi negara Asia dan Pasifik terutama sebagai penghasil kopra. Kelapa disebut pohon kehidupan karena kelapa merupakan tumbuhan serba guna yang hampir semua bagiannya bermanfaat bagi kehidupan manusia. Kemampuannya untuk berbuah pun cukup tinggi. Sebuah pohon kelapa mampu menghasilkan sekitar 40-200 butir per tahun.

Sabut kelapa adalah bahan berserat dengan ketebalan sabut kelapa sekitar 5 $\mathrm{cm}$ dan merupakan bagian paling luar dari buah kelapa. Adapun susunan sabut kelapa terdiri atas kulit ari, serat, dan sekam (dust). Berdasarkan keterangan UCAP (United Coconut Association of the Philipines), dari sebutir kelapa didapat 0,4 $\mathrm{kg}$ sabut. Sementara sabut sendiri mengandung 30\% serat. Pengolahan yang bisa dilakukan lagi adalah dari serat sabut 
kelapa, karena serat sabut kelapa ini termasuk serat kasar. Ini penting bagi bahan industri dan perdagangan, khususnya yang memakai bahan baku serat sabut kelapa yang memang tersebar di berbagai negeri penghasil kelapa. (Soekardi, 2012).

Serat/serabut kelapa membentuk struktur kulit pembungkus tempurung kelapa. Serat kelapa memiliki sifat tahan lama, kuat terhadap gesekan dan tidak mudah patah, tahan terhadap air (tidak membusuk), tahan terhadap jamur dan hama, serta tidak dihuni oleh rayap maupun tikus. (Frick\& Koesmartadi, 1999).

\section{Batang Pisang}

Pohon pisang merupakan salah satu jenis pohon yang hidup pada daerah tropis. Pohon ini biasanya memiliki tinggi hingga 2 meteran, dengan daun yang sangat lebar dan juga buah yang manis. Buahnya memang sangat populer dengan warna kuning dan juga hijau.Pohon pisang memiliki batang yang lunak dan tidak berkayu. Pisang ditanam dengan cara ditanam umbinya.

Pohon pisang banyak sekali ditemui di daerah Indonesia, mulai dari ujung barat hingga ke ujung timur dari negara Indonesia. Selain itu, di beberapa hutan hujan tropis di berbagai negara, pohon pisang juga merupakan salah satu jenis pohon yang tumbuh dengan subur, seperti di daerah Amerika Selatan dan juga Asia Selatan dan Tenggara, begitu pula dengan daerah Afrika.

Selama ini batang pisang hanya dibuang begitu saja dan menjadi tumpukan limbah. Untuk itu limbah batang pisang dimanfaatkan untuk menjadi pengisi rongga (filler) dalam papan komposit.

\section{E. Kertas Bekas}

Permasalahan sampah kertas tidak terlepas dari permasalahan sampah secara keseluruhan. Salah satu upaya pemerintah dalam mengatasi permasalahan sampah kertas antara lain dengan mendorong usaha guna ulang dan daur ulang sampah kertas.Saat ini sekitar sampah kertas dapat dikumpulkan oleh pemulung untuk dijual ke lapak. Jumlah timbunan sampah kertas bisa mencapai sekitar 10\% dari jumlah keseluruhan sampah. Masing-masing jenis kertas juga memiliki karakteristik tersendiri kemampuannya untuk didaur ulang dan prosesnya juga berbeda-beda. Sementara itu, sebagian besar kertas pembungkus makanan tidak didaur ulang, begitu pula dengan kertas tisu karena sifatnya yang mudah hancur.

Kertas jenis kalender termasuk limbah sampah yang kurang dimanfaatkan secara maksimal. Biasanya setiap pergantian tahun, selalu ada tumpukan sampah kertas bekas kalender. Hal inilah yang akan digunakan untuk dimanfaatkan dalam pembuatan papan komposit.

\section{F. Kekuatan}

Pada bending statis kekuatan komposisi papan komposit dengan menggunakan pengujian sifat mekaniknya, yaitu $\mathrm{MoE}$ dan MoR dan dibuat dalam tabulasi dandiagram.

Untuk menghitung nilai keteguhan patah (MoR) dan Modulus Elastisitas (MoE)digunakan rumus sebagai berikut :

$$
\begin{aligned}
\mathrm{MoR} & =\frac{3 \cdot \mathrm{P} \cdot \mathrm{L}}{2 \cdot 1 \cdot \mathrm{t}^{2}}\left(\mathrm{~kg} / \mathrm{cm}^{2}\right) \\
\mathrm{MoE} & =\frac{\Delta \mathrm{P} \cdot \mathrm{L} \cdot{ }^{3}}{4 \cdot 1 \cdot \Delta \mathrm{f} \cdot \mathrm{t}^{3}}\left(\mathrm{Kg} / \mathrm{cm}^{2}\right)
\end{aligned}
$$

\section{keterangan:}

$\begin{array}{ll}\text { MoR } & \text { : keteguhan lentur }\left(\mathrm{Kg} / \mathrm{cm}^{2}\right) \\ \mathrm{MoE} & : \text { keteguhan patah }\left(\mathrm{Kg} / \mathrm{cm}^{2}\right) \\ \mathrm{T} & : \text { tebal contoh uji }(\mathrm{cm}) \\ \mathrm{l} & : \text { lebar contoh uji }(\mathrm{cm}) \\ \mathrm{L} & : \text { jarak sangga }(\mathrm{cm}) \\ \Delta \mathrm{P} & \text { : besarnya gaya dalam kurve } \\ \Delta \mathrm{f} & \text { : besarnya gaya defleksi } \\ \mathrm{P} & \text { : beban yang diberikan sampai } \\ & \text { batas patah. }\end{array}$




\section{METODE PENELITIAN}

\section{A. Alat Penelitian}

1. Parang/pisau besar

2. Palu

3. Timbangan

4. Blender

5. Sendok pengaduk kayu (spatula)

6. Alas potong (talenan)

7. Penggaris ukur

8. Gelas ukur

9. Cetakan pengepresan (dua plat besi dan sebuah bingkai)

10. Alat pengempa/mesin pres

11. Gunting

12. Ember plastik

13. Alumunium foil

14. Alat uji bending Universal Testing

Machine (UTM)

\section{B. Bahan Penelitian}

1. Serat kelapa muda

2. Batang pisang

3. Kertas bekas jenis kalender

4. Larutan $\mathrm{NaOH} 4 \%$

5. Perekat kayu jenis Epoxy

6. Kit mobil

7. Air

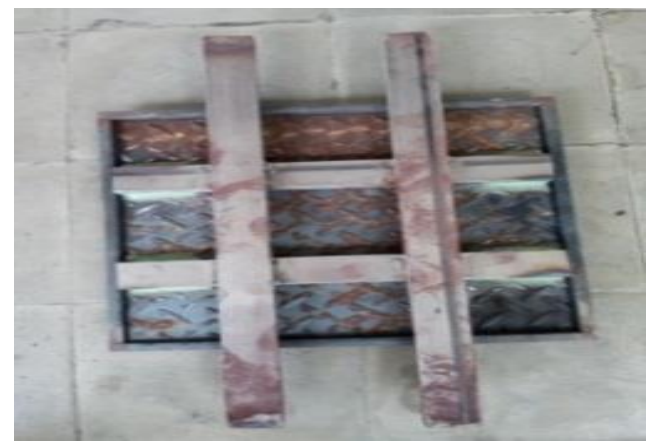

Gambar 1. Cetakan Papan Komposit

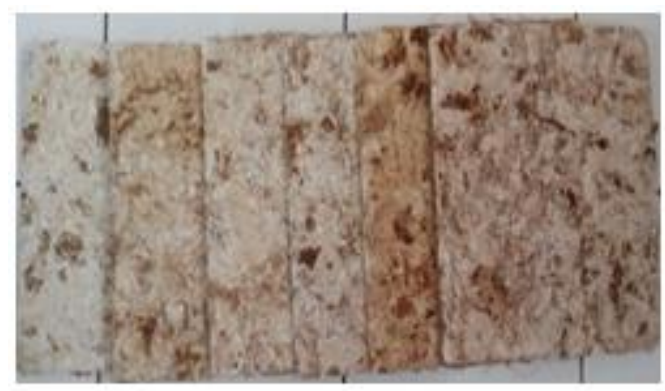

Gambar 2. Enam buah papan komposit
Gambar 2. Enam buah papan komposit dengan semua komposisi bahan baku dan waktu penghancuran (kiri - kanan) :

Waktu penghancuran 5" dengan komposisi I - II - III dan waktu penghancuran 10" dengan komposisi I - II - III.

\section{Diagram Alir Penelitian}

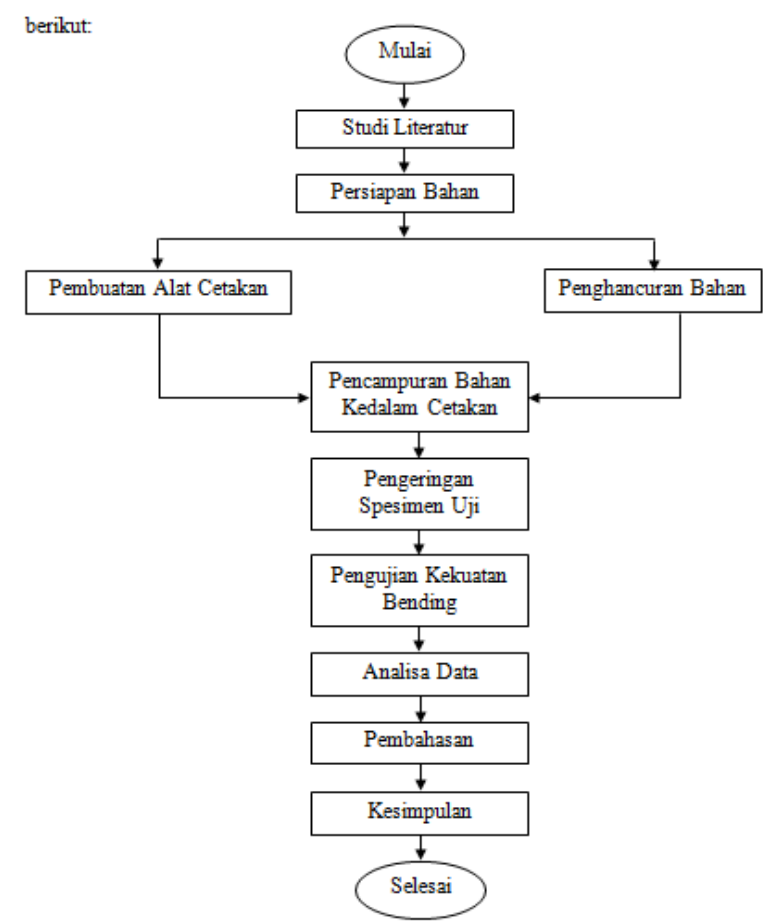

Gambar 3. Diagram alir penelitian

IV. HASIL DAN PEMBAHASAN

\section{A. Hasil Penelitian}

Tabel 1. Hasil Perhitungan Kadar Air Papan Komposit

\begin{tabular}{|c|c|c|c|c|c|}
\hline $\begin{array}{c}\text { Har } \\
\text { i } \\
\text { ke- }\end{array}$ & $\begin{array}{c}\text { Kompo } \\
\text { sisi }\end{array}$ & $\begin{array}{l}\text { Waktu } \\
\text { Peng- } \\
\text { hancur } \\
\text { an }\end{array}$ & $\begin{array}{c}\text { Bera } \\
\text { t } \\
\text { Awa } \\
\text { l } \\
\text { (gr) }\end{array}$ & $\begin{array}{c}\text { Bera } \\
\text { t } \\
\text { Akhi } \\
\mathbf{r} \\
(\mathrm{gr})\end{array}$ & $\begin{array}{l}\text { KA } \\
(\%)\end{array}$ \\
\hline 1 & \multirow{3}{*}{ I } & \multirow{3}{*}{$5 "$} & 480 & - & 100 \\
\hline 7 & & & 480 & 436 & $\begin{array}{c}10,0 \\
9\end{array}$ \\
\hline 14 & & & 436 & 407 & 7,12 \\
\hline 1 & \multirow{3}{*}{ II } & \multirow{3}{*}{$5 "$} & 832 & - & 100 \\
\hline 7 & & & 832 & 778 & 6,94 \\
\hline 14 & & & 778 & 702 & $\begin{array}{c}10,8 \\
3\end{array}$ \\
\hline 1 & \multirow{3}{*}{ III } & \multirow{3}{*}{$5 "$} & 809 & - & 100 \\
\hline 7 & & & 809 & 752 & 7,58 \\
\hline 14 & & & 752 & 689 & 9,14 \\
\hline
\end{tabular}




\begin{tabular}{|c|c|c|c|c|c|}
\hline 1 & \multirow{3}{*}{ I } & \multirow{3}{*}{$10 "$} & 452 & - & 100 \\
\hline 7 & & & 452 & 417 & 8,39 \\
\hline 14 & & & 417 & 381 & 9,45 \\
\hline 1 & \multirow{3}{*}{ II } & \multirow{3}{*}{$10 "$} & 757 & - & 100 \\
\hline 7 & & & 757 & 702 & 7,83 \\
\hline 14 & & & 702 & 626 & $\begin{array}{c}12,1 \\
4\end{array}$ \\
\hline 1 & \multirow{3}{*}{ III } & \multirow{3}{*}{$10 "$} & 740 & - & 100 \\
\hline 7 & & & 740 & 634 & $\begin{array}{c}16,7 \\
2\end{array}$ \\
\hline 14 & & & 634 & 569 & $\begin{array}{c}11,4 \\
2\end{array}$ \\
\hline
\end{tabular}

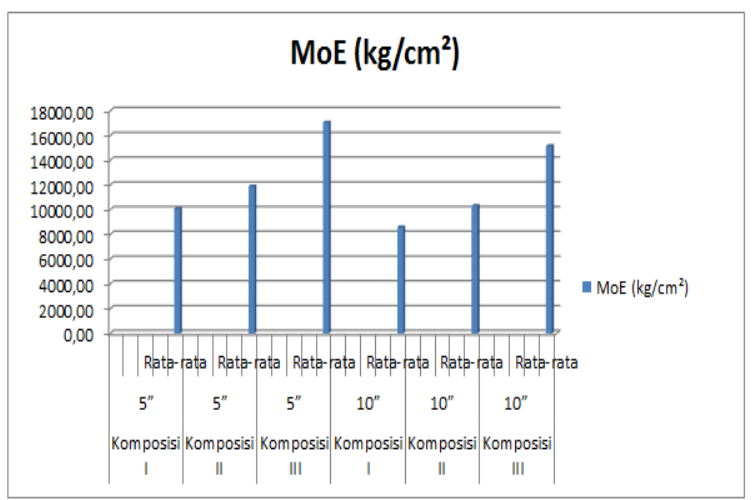

Gambar 4. Rerata Nilai MoE terhadap

Komposisi Bahan Baku dengan

Lama Waktu Penghancuran

Kadar air dihitung dari massa sampel uji sebelum dan sesudah dikeringkan dari cetakan papan partikel berukuran $30 \mathrm{~cm} \mathrm{x}$ $30 \mathrm{~cm} \times 1 \mathrm{~cm}$ dengan rumus : $\mathrm{KA}=$ $\frac{\mathrm{m}_{1-\mathrm{m}_{2}}}{\mathrm{~m}_{2}} \times 100 \%$

Keterangan:

$\mathrm{KA}=$ kadar air $(\%)$

$\mathrm{m}_{1}=$ berat awal contoh uji (gr)

$\mathrm{m}_{2}=$ berat tetap contoh uji setelah pengeringan (gr)

Kadar air merupakan jumlah air yang terkandung di dalam papan komposit serat tanaman dan kertas bekas jenis kalender. Kadar air papan komposit sangat dipengaruhi oleh kadar air partikel sebelum dilakukan pembuatan papan komposit.

Nilai rata - rata kadar air papan komposit berada diantara 6,94\% - 16,72\% (Tabel 1). Kadar air terbesar $(16,72 \%)$ diperoleh papan komposit yang dibuat pada komposisi III ( SKM 50\% : SBP 25\% : KBK 25\%) dengan lama waktu penghancuran selama 10" pada hari ke-7, dankadar air terendah $(6,94 \%)$ diperoleh papan komposit yang dibuat pada komposisi II ( SKM 25\% : SBP 50\% : KBK 25\%) dengan lama waktu penghancuran selama 5" pada hari ke-7. Semua papan komposit yang dibuat kadar airnya memenuhi syarat SNI03 - 2105 2006 (dibawah 14\%), kecuali papan komposit dengan KA terbesar, yakni sebesar $16,72 \%$. Hal ini dimungkinkan ketiga bahan campuran tersebut tidak bias saling mengikat, sehingga menimbulkan celah antar partikel, dan sifat higroskopis uap air yang lebih besar. Kondisi lingkungan (kelembaban) tempat dimana papan komposit ditempatkan juga akan berpengaruh terhadap sifat higroskopis uap air papan komposit. Bahan partikel yang lebih halus, maka daya kering airnya semakin kecil, artinya papan komposit yang dihasilkan lebih kering.

Tabel 2. Hasil Pengujian Sifat Mekanik MoE (Modulus of Elasticity) dan MoR (Modulus of Rupture)

\begin{tabular}{|c|c|c|c|c|}
\hline Perlakuan & $\begin{array}{l}\text { Waktu } \\
\text { Pengha } \\
\text { ncuran }\end{array}$ & $\begin{array}{c}\text { Pengula } \\
\text { ngan } \\
\text { Sampel }\end{array}$ & $\begin{array}{c}\mathrm{MoE} \\
\left(\mathrm{kg} / \mathrm{cm}^{2}\right)\end{array}$ & $\begin{array}{c}\mathrm{MoR} \\
(\mathrm{kg} / \mathrm{c} \\
\left.\mathrm{m}^{2}\right)\end{array}$ \\
\hline \multirow{5}{*}{ Komposisi I } & \multirow{5}{*}{$5 "$} & 1 & $9.740,23$ & 81,43 \\
\hline & & 2 & $10.501,41$ & 81,52 \\
\hline & & 3 & $10.007,21$ & 80,03 \\
\hline & & Jumlah & $30.248,85$ & $\begin{array}{c}242,9 \\
8\end{array}$ \\
\hline & & $\begin{array}{c}\text { Rata- } \\
\text { rata }\end{array}$ & $10.082,95$ & 80,99 \\
\hline \multirow{5}{*}{$\begin{array}{l}\text { Komposisi } \\
\text { II }\end{array}$} & \multirow{5}{*}{$5 "$} & 1 & $11.443,36$ & 81,73 \\
\hline & & 2 & $11.521,01$ & 82,05 \\
\hline & & 3 & $12.701,22$ & 82,52 \\
\hline & & Jumlah & $35.665,59$ & 246,3 \\
\hline & & $\begin{array}{l}\text { Rata- } \\
\text { rata }\end{array}$ & $11.888,53$ & 82,1 \\
\hline \multirow{5}{*}{$\begin{array}{l}\text { Komposisi } \\
\text { III }\end{array}$} & \multirow{5}{*}{$5 "$} & 1 & $17.364,73$ & 83,51 \\
\hline & & 2 & $16.392,01$ & 84,01 \\
\hline & & 3 & $17.452,55$ & 83,82 \\
\hline & & Jumlah & $51.209,29$ & $\begin{array}{c}251,3 \\
4\end{array}$ \\
\hline & & $\begin{array}{c}\text { Rata- } \\
\text { rata }\end{array}$ & $17.069,76$ & 83,78 \\
\hline \multirow{5}{*}{ Komposisi I } & \multirow{5}{*}{$10 "$} & 1 & $8.002,52$ & 78,52 \\
\hline & & 2 & $8.731,01$ & 79,05 \\
\hline & & 3 & $9.052,22$ & 78,21 \\
\hline & & Jumlah & $25.785,75$ & $\begin{array}{c}235,7 \\
8\end{array}$ \\
\hline & & $\begin{array}{c}\text { Rata- } \\
\text { rata }\end{array}$ & $8.595,25$ & 78,59 \\
\hline
\end{tabular}




\begin{tabular}{|c|c|c|c|c|}
\hline \multirow{5}{*}{$\begin{array}{c}\text { Komposisi } \\
\text { II }\end{array}$} & \multirow{5}{*}{$10 "$} & 1 & $10.002,64$ & 81,44 \\
\hline & & 2 & $10.573,01$ & 80,05 \\
\hline & & 3 & $10.392,96$ & 80,53 \\
\hline & & Jumlah & $30.968,61$ & $\begin{array}{c}242,0 \\
2\end{array}$ \\
\hline & & $\begin{array}{l}\text { Rata- } \\
\text { rata }\end{array}$ & $10.322,87$ & 80,67 \\
\hline \multirow{5}{*}{$\begin{array}{c}\text { Komposisi } \\
\text { III }\end{array}$} & \multirow{5}{*}{$10 "$} & 1 & $15.213,21$ & 82,52 \\
\hline & & 2 & $15.720,01$ & 81,01 \\
\hline & & 3 & $14.571,33$ & 81,73 \\
\hline & & Jumlah & $45.504,55$ & $\begin{array}{c}245,2 \\
6\end{array}$ \\
\hline & & $\begin{array}{l}\text { Rata- } \\
\text { rata }\end{array}$ & $15.168,18$ & 81,75 \\
\hline
\end{tabular}

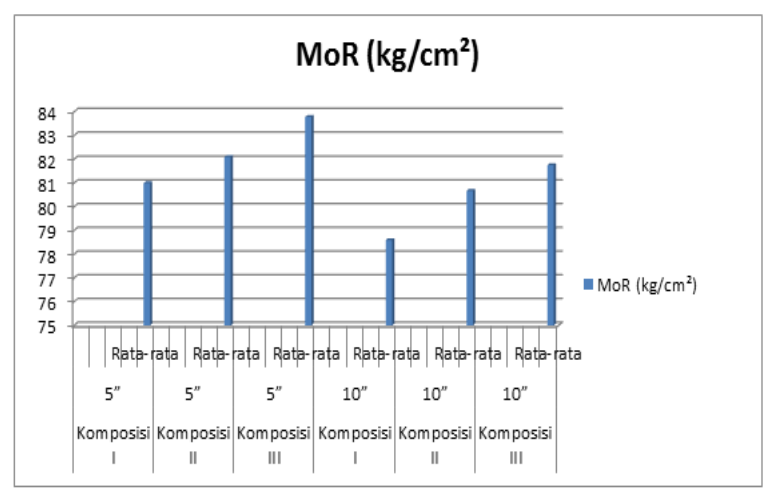

Gambar 5. Rerata Nilai MoR terhadap Komposisi Bahan Baku dengan Lama Waktu Penghancuran

Modulus of Elastisity (MOE) atau keteguhan lentur merupakan sifat mekanis yang menunjukkan sifat ketahanan papan komposit terhadap pembebanan dalam batas proporsi sebelum terjadi patah. Semakin tinggi nilai keteguhan lentur, maka benda tersebut akan semakin elastis/lentur. Rerata nilai tertinggi adalah pada komposisi III dengan lama waktu penghancuran selama 5" sebesar $17.069,76 \mathrm{~kg} / \mathrm{cm}^{2}$, dan rerata nila iterendah pada komposisi I dengan lama waktu penghancuran selama 10" sebesar $8.595,25 \mathrm{~kg} / \mathrm{cm}^{2}$. (Tabel2).

Semakin tinggi kerapatan partikel penyusun pada papan komposit, maka papan komposit yang dihasilkan maka semakin tinggi pula keteguhan lenturnya. Hal ini terjadi karena semakin tinggi kerapatan sehingga kemampuan papan menahan beban yang diberikan akan semakin tinggi maka semakin tinggi pula keteguhan lentur papan. Berdasarkan standar JIS A 5417-1992 papan komposit memiliki nilai MOE minimal 24.000 $\mathrm{kg} / \mathrm{cm} 2$. Nilai MOE yang dihasilkan dari penelitian ini tidak memenuhi standar tersebut.

Modulus of Rupture (MOR) atau keteguhan patah adalah tingkat keteguhan papan komposit dalam menerima beban tegak lurus terhadap permukaan papan. Rerata nilai keteguhan patah papan komposit berkisar antara $78,59 \mathrm{~kg} / \mathrm{cm}^{2}-$ $83,78 \mathrm{~kg} / \mathrm{cm}^{2}$. Rerata nilai MoR tertinggi dihasilkan oleh papan komposit dengan komposisi III dengan lama waktu peghancuran selama 5", sedangkan rerata nilai MoR terendah dihasilkan oleh papan komposit dengan komposisi I dengan lama waktu penghancuran selama 10". Nilai MoR yang dihasilkan papan komposit dalam penelitian ini memenuhi standar JIS A $5417-1992$ yaitu $\geq 63 \mathrm{~kg} / \mathrm{cm}^{2}$.

Dari analisis sidik ragam menunjukkan bahwa pengaruh komposisi bahan baku dan waktu proses penghancuran terhadap kekuatan bending papan komposit berpengaruh sangat nyata terhadap nilai kadar air, keteguhan patah, dan keteguhan lentur papan komposit

\section{KESIMPULAN DAN SARAN}

\section{A. Kesimpulan}

Berdasarkan hasil penelitian yang telah dilakukandapat diambil kesimpulan sebagai berikut:

1. Perlakuan yang terbaik ialah komposisi III dengan lama waktu penghancuran selama 5", yaitu dengan rerata nilai $\mathrm{MoE}$ sebesar 17.069,76 $\mathrm{kg} / \mathrm{cm}^{2}$ dan rerata nilai MoR sebesar $83,78 \mathrm{~kg} / \mathrm{cm}^{2}$.

2. Interaksi antara komposisi bahan baku dan waktu proses penghancuran terhadap kekuatan bending papan komposit berpengaruh sangat nyata terhadap nilai kadar air, keteguhan patah, dan keteguhan lentur papan komposit. 


\section{B. Saran}

Saran yang dapat disampaikan dari penelitian awal ini adalah :

1. Faktor pengadukan campuran resin perlu diperhatikan supaya adonan benar - benar homogen.

2. Penuangan komposit kedalam cetakan harus merata dan mencegah jangan sampai ada udara yang terjebak dalam cetakan.

3. Perlu dilakukan penelitian lebih lanjut untuk ukuran partikel yang homogen dari serat tanaman sehingga bisa menghasilkan kekuatan bending terbaik.

\section{UCAPAN TERIMA KASIH}

Penulis menyampaikan ucapan terima kasih yang sebesar-besarnya atas penelitian yang dibiayai oleh DIPA Kopertis Wilayah V Yogyakarta 2017.

\section{DAFTAR PUSTAKA}

Amin, M., dan Samsudi R. (2010). Pemanfaatan Limbah Serat Sabut Kelapa Sebagai Bahan Pembuat Helm Pengendara Kendaraan Roda Dua, Prosiding Seminar Nasional Unimus, ISBN : 978.979.704.883.9

Frick, H., \& Koesmartadi, C. (2012).Ilmu Bahan Bangunan (Cetakan ke-10). Penerbit Kanisius, ISBN 978-979672-444-4

Saleh, A., Pakpahan, M. M., \& Angelina, N. (2009, Agustus). PengaruhKonsentrasiPelarut, Temperatur Dan Waktu Pemasakan Pada Pembuatan Pulp Dari Sabut Kelapa Muda, No.3. Jurnal Teknik Kimia, Vol.16

Sari, N. H., Sinarep, Taufan, A., \& Yudhyadi, I. (2011).Ketahanan BendingKomposit Hybrid Serat Batang Kelapa/Serat Gelas Dengan Matrik UreaFormaldehyde.Jurnal Ilmiah Teknik Mesin Cakra M, Vol. 5 (1), hal. 91-97
Soekardi, Y. (2012).Pemanfaatan \& Pengolahan Kelapa. Yrama Widya, ISBN 978-979-077-427-8

Sucipto, C, D. (2012).Teknologi Pengolahan Daur Ulang Sampah, GosyenPublishing

Sudarsono, Rusianto, T.,\& Suryadi, Y. (2010).Pembuatan Papan Partikel Berbahan Baku Sabut Kelapa Dengan Bahan Pengikat Alami (Lem Kopal), Jurnal Teknologi, Volume 3 Nomor 1, Juni, hal. 2232 